\title{
Total phenolics, antioxidant capacity, colour and drying characteristics of date fruit dried with different methods
}

\author{
Gökçen İZLi் ${ }^{1 *}$
}

\begin{abstract}
Date slices were dried with the three drying methods convective $\left(60,70\right.$ and $\left.80^{\circ} \mathrm{C}\right)$, microwave $(120 \mathrm{~W})$ and freeze drying to determine drying characteristics and to compare the dried fruit quality. All colour parameters changed depending on the drying method and colours closest to the fresh sample were obtained with freeze drying. It is interesting to note that the total phenolic content and antioxidant capacity in each sample rose when looked at in relation to the fresh sample. In particular, microwave-dried samples were recorded as having the highest total phenolic content and the highest antioxidant capacity. To explain the drying kinetics of the date slices, nine thin-layer drying models were also attempted. Based on statistical tests, the model developed by Midilli et al. model was found to be the best model for convective and microwave drying, but the Two Term model was the best for freeze drying. This study shows that microwave drying can produce high quality date slices with the additional advantage of reduced drying times compared to convective and freeze drying.
\end{abstract}

Keywords: drying methods; thin-layer; date slices; colour; total phenolic content.

Practical Applications: Microwave drying at 120W can improve the final quality of dried date slices.

\section{Introduction}

The date (Phoenix dactylifera L.) is a fruit, which is characterized with a middle-stone and plump outer covering. It is a very nutritious fruit that is a product of a date palm. These date palm trees are native to the dry and semi-dry climates of Northern Africa and the Middle East. This fruit is very healthy as it contains many different kinds of minerals $(\mathrm{Ca}, \mathrm{Fe}, \mathrm{Mg}$, $\mathrm{P}, \mathrm{K}$ and $\mathrm{Zn}$ ), dietary fibre (6.40-11.50\%), protein (2.3-5.6\%), and carbohydrates (44-88\%, predominately glucose, fructose and sucrose). It also includes many more natural ingredients like carotenoids and phenolics that are helpful antioxidative compounds (Al-Shahib \& Marshall, 2003). This fruit is available on the global market many different forms; dried, processed, or fresh. Dates are available to be eaten in many different growth stages. For example, dates can be eaten in the khalaal stage (full-size, crunchy), rutab stage (ripe, soft) or tamer stage (ripe, sun-dried), but dried dates are the most common way that dates are sold commercially. (Ashraf \& Hamidi-Esfahani, 2011).

One of the oldest forms of processing and preserving food is drying. The main aim of drying is to extend the shelf life of certain foods, minimize packaging requirements and reduce shipping weights (Okos et al., 1992). The most common method throughout history for drying dates has been sun drying. This process of sun drying has its challenges in that daytime temperature and humidity cannot controlled, the fruit is in contact with the open environment (a possible source of contamination due to dust, soil, sand particles and insects), and the fact that the process takes too much time. Due to the downsides of this processing method, sun drying does not provide an effective process for quality production (Doymaz, 2005).

To reduce these problems, other forms of processing should be taken into consideration, which may improve quality in terms of colour or nutrients. In today's world, it seems that the most effective and common form of processing is the convective drying method, because of its ability to reduce the moisture content in food and preserved well (Mundada et al., 2010). However, there are many downsides to the convective method that must be observed. For example, the detriments of using this method include the high temperatures and the long drying times that are used. These detriments can have negative effects on the actual flavor and nutrients of the final product produced (Maskan, 2001; Zhang et al., 2006). Another alternative method to consider is the microwave drying. This method provides many advantages in using uniform energy, providing low space utilization, supplying healthy sanitation, and giving better process control (Maskan, 2000). At the same time, as each method is analyzed, it is noteworthy that every method has some drawbacks. For example, the microwave method can cause uneven heating, can be high investment cost, and can cause damage to the final product (Zhang et al., 2006). Freeze drying is a well-known drying process for obtaining high quality products because it reduces nutritional and sensorial degradation. On the other hand, the freeze drying method also requires a lot of time and is known as the most expensive form of food drying process (Ratti, 2001). 
According to literature surveys, there is not much work being published about date fruit drying methods. A careful evaluation of all of the methods must take place before selecting a suitable method for commercial drying. Hence, the objectives of this study were to compare the 1) thin-layer drying kinetics 2) colour change parameters, 3) total phenolic content and 4) antioxidant capacity of dried date fruits when using convective-, microwave- and freeze drying methods.

\section{Materials and methods}

\subsection{Date fruits}

For this study, date samples were purchased from a local market in Bursa, Turkey. These samples were stored at a temperature of $4 \pm 0.5^{\circ} \mathrm{C}$ until the drying process was completed. The initial moisture content on a dry basis (d.b.) was determined to be 1.87 (g water/g dry solid) by oven drying (ED115 Binder, Tuttlingen, Germany) at $100 \pm 5^{\circ} \mathrm{C}$. Fruits that were uniformly matured and undamaged were used for all experiments in this study. Each date sample was sliced with a food slicer (Nicer Dicer, China) to get the following measurements; each sample averaged out to have a $25 \pm 0.05 \mathrm{~mm}$ diameter and was sliced to have a $5 \pm 0.05 \mathrm{~mm}$ thickness.

\subsection{Equipment and procedures for drying}

Three different methods were used in the following experiments. The methods used were; convective drying, microwave drying, and freeze drying. These experiments were implemented in triplicate. Convective drying: Date slices were put on a rotating glass plate with a diameter of $400 \mathrm{~mm}$ in thin layer and then dried using a laboratory convective oven (Whirlpool AMW 545, Turkey). At the time of the experiment, the air velocity was $1.5 \mathrm{~m} / \mathrm{s}$, with air temperatures of 60,70 and $80^{\circ} \mathrm{C}$. A digital balance (Shimadzu UX-6200H, Tokyo, Japan) with $0.01 \mathrm{~g}$ precision was put under the oven in order to mass determination. While the drying took place, the loss of moisture was recorded in 5-min intervals. Microwave drying: The drying treatment was performed in a microwave oven (Arçelik MD574, İstanbul, Turkey) at an output power level of $120 \mathrm{~W}$. Date slices were placed in thin layer on a rotating glass plate with a $245 \mathrm{~mm}$ diameter. The moisture loss from the sample was recorded at 2-min intervals by removing the sample with the glass plate and weighing it on the digital balance (Radwag PC 4500/C/2, Radom, Poland) with a precision of 0.01 g. Freeze drying: A laboratory freeze dryer (Alpha 1-2 LD Plus, Osterode am Harz, Germany) was used in this experiment at a processing temperature of $-50{ }^{\circ} \mathrm{C}$ with a constant pressure in the drying chamber of $48 \mathrm{~Pa}$. During drying, moisture loss from the sample was recorded every $2 \mathrm{~h}$ with an accuracy of $\pm 0.01 \mathrm{~g}$ (Radwag PC 4500/C/2, Radom, Poland).

\subsection{Mathematical modelling of drying data}

There were nine common drying models used in this experiment. The best model for describing the drying characteristics of the date slices is displayed in Table 1. During the drying process, the moisture ratios $(M R)$ were calculated with the following Equation 1:
Table 1. Thin-layer drying models being used to mathematically model the date drying kinetics.

\begin{tabular}{|c|c|c|c|}
\hline No & $\begin{array}{c}\text { Model } \\
\text { name }\end{array}$ & Model & References \\
\hline 1 & $\begin{array}{l}\text { Henderson } \\
\text { \& Pabis }\end{array}$ & $M R=a \exp (-k t)$ & $\begin{array}{c}\text { Westerman et al. } \\
\text { (1973) }\end{array}$ \\
\hline 2 & Newton & $M R=\exp (-k t)$ & Ayensu (1997) \\
\hline 3 & Page & $M R=\exp \left(-k t^{n}\right)$ & $\begin{array}{l}\text { Agrawal \& Singh } \\
\quad(1977)\end{array}$ \\
\hline 4 & Logarithmic & $M R=a \exp (-k t)+c$ & $\begin{array}{l}\text { Yagcioglu et al. } \\
\text { (1999) }\end{array}$ \\
\hline 5 & Two Term & $M R=a \exp \left(-k_{0} t\right)+b \exp \left(-k_{1} t\right)$ & $\begin{array}{l}\text { Madamba et al. } \\
\text { (1996) }\end{array}$ \\
\hline 6 & $\begin{array}{l}\text { Two Term } \\
\text { Exponential }\end{array}$ & $M R=a \exp (-k t)+(1-a) \exp (-k a t)$ & $\begin{array}{c}\text { Sharaf- } \\
\text { Eldeen et al. } \\
(1980)\end{array}$ \\
\hline 7 & $\begin{array}{l}\text { Wang \& } \\
\text { Singh }\end{array}$ & $M R=1+a t+b t^{2}$ & $\begin{array}{l}\text { Wang \& Singh } \\
\quad(1978)\end{array}$ \\
\hline 8 & $\begin{array}{l}\text { Diffusion } \\
\text { Approach }\end{array}$ & $M R=a \exp (-k t)+(1-a) \exp (-k b t)$ & Kassem (1998) \\
\hline 9 & Midilli et al. & $M R=a \exp \left(-k t^{n}\right)+b t$ & $\begin{array}{l}\text { Midilli et al. } \\
\qquad(2002)\end{array}$ \\
\hline
\end{tabular}

$M R=\frac{M_{t}-M_{e}}{M_{o}-M_{e}}$

$M_{t}$ represents the moisture at a specific time (g water/g dry solid). $M_{o}$ displays the initial moisture content (g water/g dry solid). $M_{e}$ shows the equilibrium moisture content (g water/g dry solid). When compare $M_{t}$ and $M_{o}$ with $M_{e}$, the values of $M_{e}$ turn out to be very small. In conclusion to these findings, many researchers simplified the $M R$ as follows (Equation 2) (Midilli et al., 2002):

$M R=\frac{M_{t}}{M_{o}}$

\subsection{Colour analysis}

Through the usage of a colorimeter (MSEZ-4500L, HunterLab, Virginia, USA), the colour of fresh and dried fruit slices was determined. The results for the colours were as follows: L-values (lightness/darkness), a-values (redness/greenness) and b-values (yellowness/blueness). The colorimeter was calibrated by using a standard white and black plate. A sample inside of a glass cell was placed close to the nose cone of the colorimeter, above the light source, while the $L^{*}, a^{*}$ and $b^{*}$ values measured (Xiao et al., 2012). $L_{0}^{*}, a_{0}^{*}$ and $b_{0}^{*}$ are the colour values of fresh samples. The reading was performed on the surface of sample while ten random locations were chosen for measurement. The $L^{*}$, $a^{*}$ and $b^{*}$ values were used for calculating Chroma $C$ (Equation 3 ), hue angle a Equation 4) and total colour differences $\Delta \mathrm{E}$ (Equation 5) to explain colour changes (Maskan, 2001):

$$
\begin{aligned}
& C=\sqrt{\left(a^{2}+b^{2}\right)} \\
& \alpha=\tan ^{-1}\left(\frac{b}{a}\right)
\end{aligned}
$$


$\Delta E=\sqrt{\left(L^{*}-L_{0} *\right)^{2}+\left(a *-a_{0} *\right)^{2}+\left(b^{*}-b_{0} *\right)^{2}}$

(5)

\subsection{Preparation of sample extracts}

Date fruit extracts were prepared according to the method described by Turkmen et al. (2005). Briefly, $1 \mathrm{~g}$ of sample was mixed with $4.5 \mathrm{~mL}$ methanol/water $(80 / 20 \mathrm{v} / \mathrm{v})$ using a mechanical shaker (Biosan OS-20, Latvia) at $140 \mathrm{rpm}$ for $2 \mathrm{~h}$, followed by centrifuged at $10,000 \mathrm{~g}$ for $15 \mathrm{~min}$ (Sigma 3K30, UK). Supernatants were collected, and residues were re-extracted under identical conditions. The obtained supernatants were combined and passed through a $0.45 \mu \mathrm{m}$ PTFE membrane filter.

\subsection{Total phenolic content determination}

Total phenolic content of the extracts was quantified according to the Folin-Ciocalteu test by using the method of Igual et al. (2012) with a minor modifications. $1.25 \mathrm{~mL}$ of Folin-Ciocalteu reagent (Sigma-Aldrich, Germany) and $15 \mathrm{~mL}$ of distilled water were added to $0.25 \mathrm{~mL}$ of methanolic extracts and vortexed (WiseMix VM-10, Daihan, Korea) for $15 \mathrm{~s}$. After the $8 \mathrm{~min}$ incubation in darkness, $3.75 \mathrm{~mL}$ of $7.5 \% \mathrm{Na}_{2} \mathrm{CO}_{3}$ was added to the mixture and the volume was adjusted to $25 \mathrm{~mL}$ with distilled water. Absorbance values of samples were measured at $765 \mathrm{~nm}$ (Optizen 3220 UV, Mecasys, Korea), followed by a $2 \mathrm{~h}$ incubation in the dark at room temperature. The calibration curve was prepared with gallic acid (GA) (Sigma-Aldrich, Germany), and the results were expressed as mg GA/100 g on dry weight (d.w). Three replicates of each date extract were analysed.

\subsection{Antioxidant capacity determination}

Based on the DPPH (2,2-Diphenyl-1-picrylhydrazyl) free radical scavenging method by Alothman et al. (2009), the antioxidant capacity of the extracts were measured. To $3.9 \mathrm{~mL}$ of $25 \mathrm{mM}$ methanolic solution of DPPH radical, $0.1 \mathrm{~mL}$ of appropriately diluted extracts was added. The mixture was thoroughly vortexed (WiseMix VM-10, Daihan, Korea), followed by incubation in the dark at room temperature for $30 \mathrm{~min}$. The absorbance of each sample was measured at $515 \mathrm{~nm}$ (Optizen $3220 \mathrm{UV}$, Mecasys, Korea). Results were expressed as $\mu \mathrm{mol}$ Trolox equivalents (TE) (Merck, Germany) per $1 \mathrm{~g}$ d.w. of sample. Three replicates of each date extract were analysed.

\subsection{Statistical analysis}

The experiments were conducted using a randomized plots factorial experimental design. The results were analysed by using the MATLAB (MathWorks Inc., Natick, MA) and JMP (Version 7.0, SAS Institute Inc., Cary, NC, USA). By using a least significant difference (LSD) test at a $5 \%$ level of significance, the mean differences were evaluated. The model that best explains the thin-layer drying characteristics of date fruit slices is determine as by the lowest reduced chi-squared $\left(\chi^{2}\right)$ and the root mean square error (RMSE) values, and the highest coefficient of determination $\left(R^{2}\right)$ (Goyal et al., 2006).

These values are displayed below (Equations 6, 7):
$\chi^{2}=\frac{\sum_{\dot{Y}=1}^{N}\left(M R_{\exp , i}-M R_{p r e, i}\right)^{2}}{N-n}$

$R M S E=\sqrt{\frac{\sum_{\dot{Y}=1}^{n}\left(M R_{\text {pre }, i}-M R_{\exp , i}\right)}{N}}$

$M R_{\text {exp,i }}$, represents the experimental moisture ratio for test $i$.

$\mathrm{MR}_{\text {pre,i }}$, represent the estimated moisture ratio for test $\mathrm{i}$.

$\mathrm{N}$ represents the observation number. Lastly, $\mathrm{n}$ is the number of constants in the drying model (Wang et al., 2007).

\section{Results and discussions}

\subsection{Drying kinetics}

The changes in moisture content of the date slices with drying time, drying temperature $\left(60,70\right.$ and $\left.80^{\circ} \mathrm{C}\right)$, and microwave and freeze drying are presented in Figure 1. The experimental results show that the time required to reduce the moisture content was dependent on the drying method. Drying took longest with freeze drying (1800 min) and was much faster with microwave drying (16 min). A significant reduction in drying time was realized as an increase in temperature from 60 to $80^{\circ} \mathrm{C}$ occurred. It has been shown that increasing the temperature speeds up the drying time of date fruit. This result is in good agreement with earlier observations (Garau et al., 2007; Wang et al., 2007; Tunde-Akintunde \& Ogunlakin, 2013; Faal et al., 2015). Drying time at $80{ }^{\circ} \mathrm{C}(75 \mathrm{~min})$ was $95.3 \%$ shorter than freeze drying but $78.7 \%$ longer than microwave drying at power of $120 \mathrm{~W}$. Microwave drying probably save time because the internal heat generated by the microwave causes rapid evaporation of water. Tavakolipour \& Zirjani (2014) showed that microwave drying of banana slices reduced the drying time by $90 \%$ compared to hot air drying. In studies done by Maskan (2000) and Albanese et al. (2013), they had very similar findings.

\subsection{Fitting of drying curves}

The statistical parameters, including drying model coefficients and the comparison criteria used to evaluate the fitting quality, $R^{2}, R M S E$ and $\chi^{2}$, are given in Table 2 and 3 . The $R^{2}$ values varied between 0.9247 and $0.9997, R M S E$ values varied between 0.0058 and 0.0957 and $\chi^{2}$ values varied between $0.2528 \times 10^{-4}$ and $87.7333 \times 10^{-4}$, indicating good fitting results. It is noteworthy that higher $R^{2}$ and lower RMSE and $\chi^{2}$ values were displayed through the use of the Midilli et al. model for all temperatures and at a microwave power of $120 \mathrm{~W}$. Additionally, the Two Term model gave better statistical values than other models for freeze drying. The $R^{2}, R M S E$ and $\chi^{2}$ values of the Midilli et al. and Two Term models ranged from 0.9970 to $0.9997,0.0058$ to 0.0152 and $0.2528 \times 10^{-4}$ to $2.1221 \times 10^{-4}$; and 0.9784 to 0.9977 , 0.0135 to 0.0513 and $1.6582 \times 10^{-4}$ to $25.8357 \times 10^{-4}$, respectively.

The experimental and predicted moisture ratios of the most appropriate models are presented in Figure 2 and Figure 3. Overall, there is excellent agreement between the experimental data and the predicted results. Thus, the Midilli et al. and Two Term models were found to be best models to represent the thin-layer 


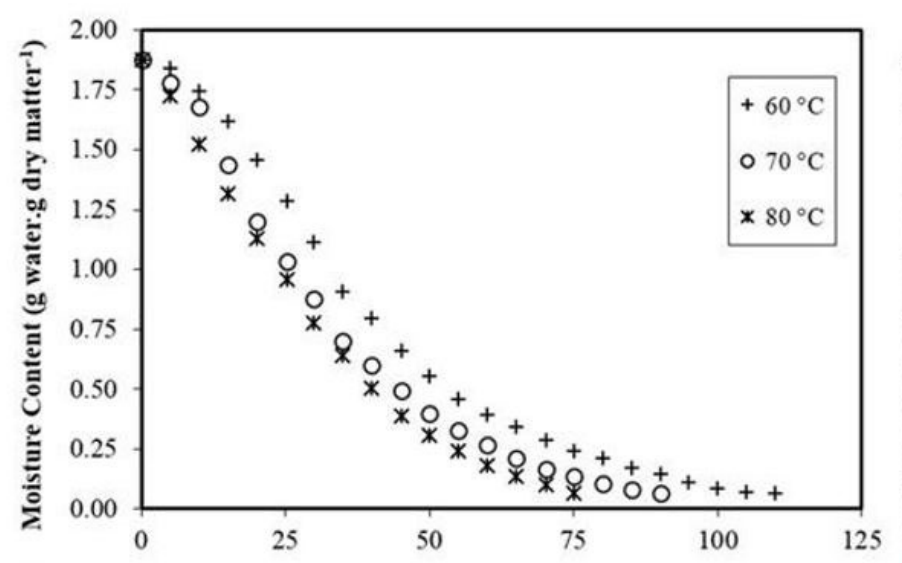

a

Time (min)
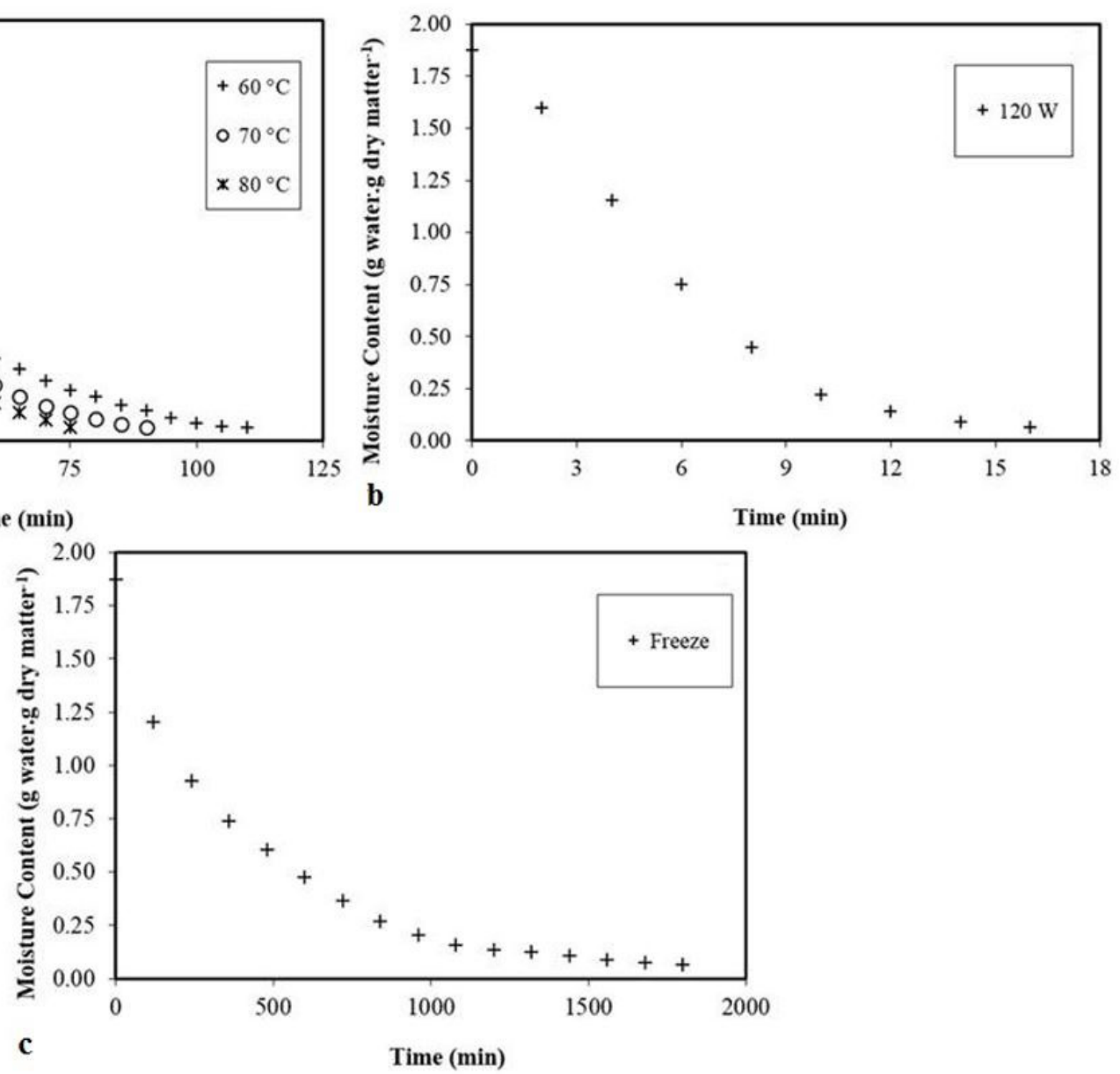

Figure 1. Drying curves of date samples using different convective temperatures (a), microwave power level (b) and freeze drying (c) conditions.

Table 2. Estimated values of coefficients and statistical essentials collected from various thin-layer drying models at different temperatures.

\begin{tabular}{|c|c|c|c|c|c|c|c|c|c|c|c|c|}
\hline \multirow{2}{*}{ No } & \multicolumn{4}{|c|}{$60^{\circ} \mathrm{C}$} & \multicolumn{4}{|c|}{$70^{\circ} \mathrm{C}$} & \multicolumn{4}{|c|}{$80^{\circ} \mathrm{C}$} \\
\hline & Model coefficients & $\mathrm{R}^{2}$ & RMSE & $\chi^{2}\left(10^{-4}\right)$ & Model coefficients & $\mathrm{R}^{2}$ & RMSE & $\chi^{2}\left(10^{-4}\right)$ & Model coefficients & $\mathrm{R}^{2}$ & RMSE & $\chi^{2}\left(10^{-4}\right)$ \\
\hline 1 & $\begin{aligned} \mathrm{a} & =1.16 \\
\mathrm{k} & =0.02753\end{aligned}$ & 0.9634 & 0.0667 & 44.1368 & $\begin{array}{l}\mathrm{a}=1.125 \\
\mathrm{k}=0.03321\end{array}$ & 0.9724 & 0.0567 & 32.3309 & $\begin{aligned} \mathrm{a} & =1.096 \\
\mathrm{k} & =0.03638\end{aligned}$ & 0.9724 & 0.0559 & 30.8148 \\
\hline 3 & $\begin{array}{l}\mathrm{k}=0.00197 \\
\mathrm{n}=1.652\end{array}$ & 0.9986 & 0.0130 & 1.7176 & $\begin{array}{l}\mathrm{k}=0.004744 \\
\mathrm{n}=1.504\end{array}$ & 0.9989 & 0.0114 & 1.5244 & $\begin{array}{l}\mathrm{k}=0.006856 \\
\mathrm{n}=1.448\end{array}$ & 0.9983 & 0.0136 & 1.6537 \\
\hline 5 & $\begin{aligned} \mathrm{a} & =-0.2754 \\
\mathrm{k}_{\mathrm{o}} & =5.323 \\
\mathrm{~b} & =1.275 \\
\mathrm{k}_{1} & =0.03012\end{aligned}$ & 0.9784 & 0.0513 & 25.8357 & $\begin{aligned} \mathrm{a} & =1.243 \\
\mathrm{k}_{\mathrm{o}} & =0.03652 \\
\mathrm{~b} & =-0.2426 \\
\mathrm{k}_{1} & =4.163\end{aligned}$ & 0.9858 & 0.0407 & 16.5055 & $\begin{aligned} \mathrm{a} & =24.01 \\
\mathrm{k}_{\mathrm{o}} & =0.06367 \\
\mathrm{~b} & =-22.97 \\
\mathrm{k}_{1} & =0.06597\end{aligned}$ & 0.9943 & 0.0253 & 5.9417 \\
\hline 6 & $\begin{array}{l}\mathrm{a}=1.022 \\
\mathrm{k}=0.01932\end{array}$ & 0.9655 & 0.0648 & 41.9409 & $\begin{array}{l}\mathrm{a}=0.0000059 \\
\mathrm{k}=504.3\end{array}$ & 0.9549 & 0.0724 & 53.4497 & $\begin{array}{l}\mathrm{a}=0.0000092 \\
\mathrm{k}=360.9\end{array}$ & 0.9605 & 0.0668 & 44.6484 \\
\hline 9 & $\begin{array}{l}\mathrm{a}=1.014 \\
\mathrm{k}=0.002189 \\
\mathrm{n}=1.631 \\
\mathrm{~b}=-0.00000498\end{array}$ & 0.9987 & 0.0126 & 1.5324 & $\begin{array}{l}\mathrm{a}=1.012 \\
\mathrm{k}=0.005768 \\
\mathrm{n}=1.448 \\
\mathrm{~b}=-0.0001453\end{array}$ & 0.9990 & 0.0110 & 1.4541 & $\begin{array}{l}\mathrm{a}=0.9972 \\
\mathrm{k}=0.00867 \\
\mathrm{n}=1.356 \\
\mathrm{~b}=-0.0006357\end{array}$ & 0.9997 & 0.0058 & 0.2528 \\
\hline
\end{tabular}


Table 3. Estimated values of coefficients and statistical essentials collected from various thin-layer drying models microwave and freeze drying conditions.

\begin{tabular}{|c|c|c|c|c|c|c|c|c|}
\hline \multirow[b]{2}{*}{ No } & \multicolumn{4}{|c|}{ Microwave } & \multicolumn{4}{|c|}{ Freeze } \\
\hline & $\begin{array}{c}\text { Model } \\
\text { coefficients }\end{array}$ & $\mathrm{R}^{2}$ & RMSE & $\chi^{2}\left(10^{-4}\right)$ & $\begin{array}{c}\text { Model } \\
\text { coefficients }\end{array}$ & $\mathrm{R}^{2}$ & RMSE & $\chi^{2}\left(10^{-4}\right)$ \\
\hline 1 & $\begin{array}{l}\mathrm{a}=1.088 \\
\mathrm{k}=0.1862\end{array}$ & 0.9550 & 0.0803 & 64.4687 & $\begin{array}{l}\mathrm{a}=0.9519 \\
\mathrm{k}=0.002602\end{array}$ & 0.9909 & 0.0268 & 6.9931 \\
\hline 2 & $\mathrm{k}=0.1731$ & 0.9513 & 0.0836 & 70.4025 & $\mathrm{k}=0.002736$ & 0.9888 & 0.0296 & 8.4459 \\
\hline 3 & $\begin{array}{l}\mathrm{k}=0.04973 \\
\mathrm{n}=1.658\end{array}$ & 0.9994 & 0.0089 & 0.5308 & $\begin{array}{l}\mathrm{k}=0.006943 \\
\mathrm{n}=0.8496\end{array}$ & 0.9952 & 0.0194 & 3.5584 \\
\hline 4 & $\begin{array}{l}\mathrm{a}=1.286 \\
\mathrm{k}=0.1211 \\
\mathrm{c}=-0.2311\end{array}$ & 0.9784 & 0.0557 & 31.2405 & $\begin{array}{l}\mathrm{a}=0.9492 \\
\mathrm{k}=0.002655 \\
\mathrm{c}=0.005606\end{array}$ & 0.9903 & 0.0276 & 7.4329 \\
\hline 5 & $\begin{aligned} \mathrm{a} & =-62.45 \\
\mathrm{k}_{\mathrm{o}} & =0.3412 \\
\mathrm{~b} & =63.47 \\
\mathrm{k}_{1} & =0.3362\end{aligned}$ & 0.9910 & 0.0358 & 13.3582 & $\begin{aligned} \mathrm{a} & =0.8359 \\
\mathrm{k}_{\mathrm{o}} & =0.002291 \\
\mathrm{~b} & =0.1641 \\
\mathrm{k}_{1} & =0.4768\end{aligned}$ & 0.9977 & 0.0135 & 1.6582 \\
\hline 6 & $\begin{array}{l}\mathrm{a}=2.132 \\
\mathrm{k}=0.2831\end{array}$ & 0.9960 & 0.0238 & 5.6057 & $\begin{array}{l}\mathrm{a}=0.1518 \\
\mathrm{k}=0.01547\end{array}$ & 0.9970 & 0.0154 & 2.1635 \\
\hline 7 & $\begin{array}{l}\mathrm{a}=-0.1251 \\
\mathrm{~b}=0.003866\end{array}$ & 0.9873 & 0.0427 & 18.3072 & $\begin{array}{l}\mathrm{a}=-0.001602 \\
\mathrm{~b}=0.0006164\end{array}$ & 0.9692 & 0.0580 & 37.2475 \\
\hline 8 & $\begin{array}{l}\mathrm{a}=14.16 \\
\mathrm{k}=0.06767 \\
\mathrm{~b}=0.9239\end{array}$ & 0.9758 & 0.0589 & 30.2738 & $\begin{array}{l}\mathrm{a}=0.1113 \\
\mathrm{k}=0.1841 \\
\mathrm{~b}=0.01321\end{array}$ & 0.9968 & 0.0157 & 2.0779 \\
\hline 9 & $\begin{array}{l}\mathrm{a}=0.9987 \\
\mathrm{k}=0.05029 \\
\mathrm{n}=1.645 \\
\mathrm{~b}=-0.0003728\end{array}$ & 0.9995 & 0.0083 & 0.5088 & $\begin{array}{l}\mathrm{a}=0.9955 \\
\mathrm{k}=0.01014 \\
\mathrm{n}=0.7787 \\
\mathrm{~b}=-0.00000219\end{array}$ & 0.9970 & 0.0152 & 2.1221 \\
\hline
\end{tabular}

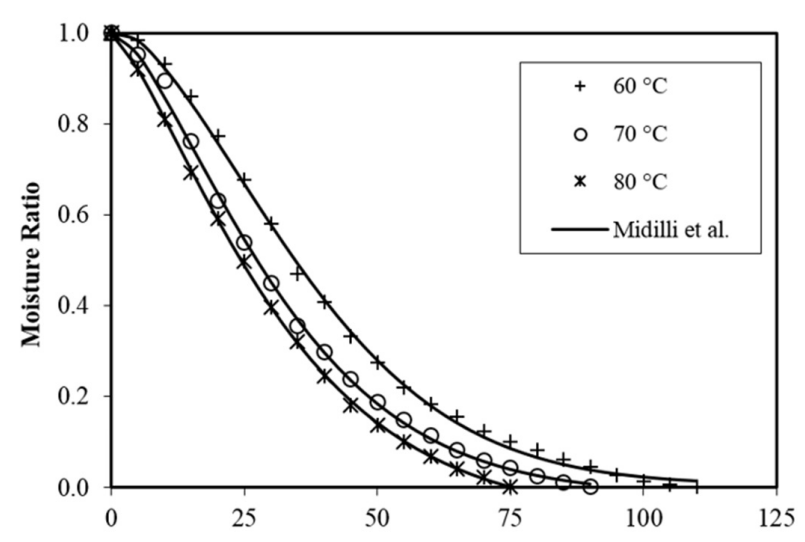

a

Time (min)

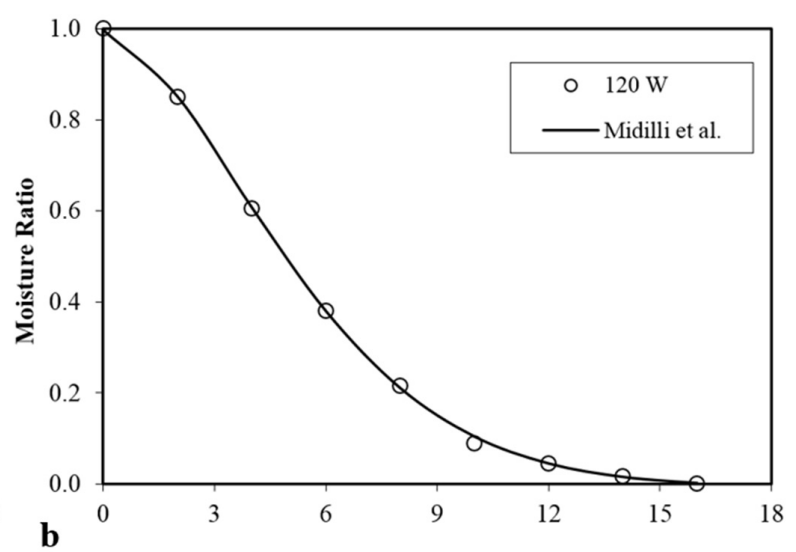

Time (min)

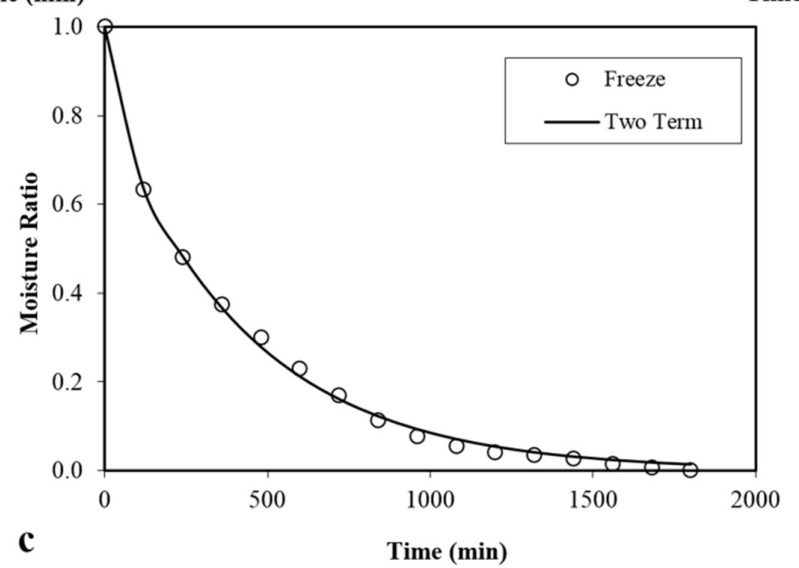

Figure 2. A comparison of the experimental and theoretical moisture ratios that was put forth by the Midilli et al. and Two Term models at specific drying times under three selected drying conditions; convective (a), microwave (b), freeze (c). 
drying characteristics of the date slices. These observations are in good agreement with earlier results reported for the Midilli et al. model in describing the thin-layer drying of pear (Doymaz, 2013) and mango ginger (Murthy \& Manohar, 2014) and for the Two term model in drying of sultana grapes (Yaldiz et al., 2001) and squash seeds (Chayjan et al., 2013).

\subsection{Colour analysis}

The colour of a product is an important attribute for quality assessment. The colour parameters of the dried date fruits were influenced by the different drying methods, as shown in Table 4. In comparison to the fresh date fruit, a significant decline in the $L^{*}$ value was observed $(P<0.05)$. The $L^{*}$ of the freeze-dried samples was significantly higher than those of convective- and microwave-dried dates $(P<0.05)$. In contrast, a significant increase in $a^{*}$ values was observed compared to the fresh samples in fruits dried with convective and microwave drying $(P<0.05)$. The changes in $L^{*}$ and $a^{*}$ values in dried fruits seemed to follow similar trends, but there were some variations within the $b^{*}$ values for all drying methods. Of the three drying methods used, the highest $b^{*}$ value was found with convective drying at $80^{\circ} \mathrm{C}$, and the largest decrease in $b^{*}$ value was found with microwave drying at $120 \mathrm{~W}$. Generally the $b^{*}$ value of dried dates was lower than that of fresh samples. However, the $b^{*}$ value increased with increasing temperature for the convective $\left(80^{\circ} \mathrm{C}\right)$ dried samples. $\Delta E$, which is a function of

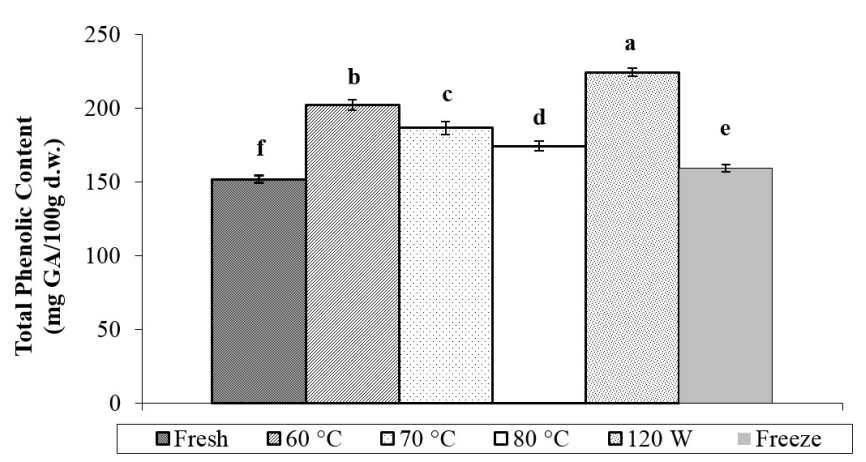

Figure 3. The effects of different drying conditions on the total phenolic content of dates. Bars that display different letters are shown as significantly different $(P<0.05)$.
$L^{*}, a^{\star}$ and $b^{*}$ values, was dependent on drying temperature and drying method. A decrease in $L^{*}$ value of a sample resulted in higher $\Delta E$. Microwave drying (17.33) produced the highest $\Delta E$, and the lowest $\Delta E$ value was obtained with freeze drying (3.42). A good way to recognize the colour intensity was to look at the $C$ value. Compared to fresh sample, the $C$ values of microwave and freeze dried samples were reduced $(P<0.05)$. In contrast, as drying temperature increased from 60 to $80^{\circ} \mathrm{C}$ in convective drying, higher $C$ values were obtained, mainly due to the higher $b^{*}$ values. A reduction was experienced in the values of the dried samples when looked at in relation to the fresh samples $(P<0.05)$, which clearly indicates that more browning occurred. This is probably due to the higher $a^{*}$ values of all dried samples $(P<0.05)$. Among the all dried date samples, the best colour values were obtained from the non-thermal method of freeze drying. Date fruit colour changes caused by thermal treatment may be strongly related to pigment degradation, especially the degradation of carotenoids and the formation of brown pigments by non-enzymatic reactions (Maillard reaction) and enzymatic reactions (Kammoun Bejar et al., 2011).

\subsection{Total phenolic content}

The total phenolic content of date fruit and the effects of the drying are displayed within Figure 3. The total phenolic content varied significantly with drying method $(P<0.05)$. The total phenolic content of fresh date slices was $151.79 \mathrm{mg} \mathrm{GA} / 100 \mathrm{~g}$ d.w., which is within the range of values found in other studies of dates (Allaith, 2008; Singh et al., 2012). The results show that dried fruits had higher total phenolic content than fresh fruit. The highest total phenolic content (224.52 $\mathrm{mg} \mathrm{GA} / 100 \mathrm{~g}$ d.w.) was obtained by microwave drying at $120 \mathrm{~W}$, whereas the lowest total phenolic content was obtained by freeze drying (159.23 mg GA/100 g) $(P<0.05)$. During studies using the convective drying method, the total phenolic content declined when the drying temperature was increased from 60 to $80{ }^{\circ} \mathrm{C}(P<0.05)$. The decrease in total phenolic with increasing drying temperature has also been reported in studies of pear (Santos et al., 2014) and apple (Vega-Gálvez et al., 2012). The increase in total phenolic content in dried samples may occur because the drying treatments accelerate bound phenolic compounds as part of the breakdown of cellular constituents (Chang et al., 2006). In this study, the increase could be explained by the degradation of complex phenolic tannins by heat and enzymatic or non-enzymatic oxidation, which

Table 4. Colour parameters of fresh and dried dates which were determined by using different drying methods.

\begin{tabular}{|c|c|c|c|c|c|c|}
\hline \multirow{2}{*}{ Drying method } & \multicolumn{6}{|c|}{ Colour parameters } \\
\hline & $L^{*}$ & $a^{*}$ & $b^{*}$ & $C$ & $\alpha^{\circ}$ & $\Delta e$ \\
\hline Fresh & $64.92 \pm 1.46^{\mathrm{a}}$ & $4.18 \pm 0.87^{\mathrm{e}}$ & $35.05 \pm 1.56^{\mathrm{a}}$ & $35.30 \pm 1.62^{b c}$ & $83.27 \pm 1.24^{\mathrm{a}}$ & \\
\hline \multicolumn{7}{|l|}{ Convective drying } \\
\hline $60^{\circ} \mathrm{C}$ & $58.29 \pm 1.73^{c}$ & $6.05 \pm 0.89^{c}$ & $31.69 \pm 1.58^{c}$ & $32.27 \pm 1.71^{\mathrm{de}}$ & $79.28 \pm 1.08^{c}$ & $7.90 \pm 1.50^{c}$ \\
\hline $70^{\circ} \mathrm{C}$ & $56.61 \pm 1.94^{\mathrm{d}}$ & $7.53 \pm 0.73^{b}$ & $34.61 \pm 1.76^{\mathrm{ab}}$ & $35.43 \pm 1.85^{\mathrm{b}}$ & $77.78 \pm 0.75^{\mathrm{d}}$ & $9.19 \pm 1.75^{\mathrm{c}}$ \\
\hline $80^{\circ} \mathrm{C}$ & $54.25 \pm 1.38^{\mathrm{e}}$ & $10.24 \pm 1.45^{\mathrm{a}}$ & $35.63 \pm 1.80^{\mathrm{a}}$ & $37.09 \pm 2.04^{\mathrm{a}}$ & $74.05 \pm 1.67^{\mathrm{e}}$ & $12.41 \pm 1.96^{\mathrm{b}}$ \\
\hline \multicolumn{7}{|l|}{ Microwave drying } \\
\hline $120 \mathrm{~W}$ & $49.27 \pm 1.85^{\mathrm{f}}$ & $9.66 \pm 0.21^{\mathrm{a}}$ & $30.33 \pm 2.10^{c}$ & $31.83 \pm 2.01^{\mathrm{e}}$ & $72.31 \pm 1.12^{\mathrm{f}}$ & $17.33 \pm 2.14^{\mathrm{a}}$ \\
\hline Freeze drying & $63.11 \pm 2.20^{\mathrm{b}}$ & $5.06 \pm 0.48^{\mathrm{d}}$ & $33.31 \pm 1.46^{\mathrm{b}}$ & $33.70 \pm 1.44^{\mathrm{cd}}$ & $81.38 \pm 0.36^{b}$ & $3.42 \pm 1.45^{\mathrm{d}}$ \\
\hline
\end{tabular}


cause more phenolics to be extracted. In addition, the increase in phenolic content could be explained by the formation of Maillard reaction products, which would cause new phenolic compounds to form from precursors during thermal treatments (Que et al., 2008; Sultana et al., 2012). The highest phenolic content in microwave-dried dates might be because of the high temperatures reached in the during microwave treatment, which could cause greater cell disruption and lead to rupturing that releases phenolic compounds. The effects of drying treatments on the phenolic compounds of foods have been studied before. Some previous studies showed that heat treatment is very effective for increasing the total phenolic content in different foods, such as dried apricots (Sultana et al., 2012), tomatoes (Chang et al., 2006) and raisins (Carranza-Concha et al., 2012). Although some authors (Zanoelo et al., 2006; Sultana et al., 2012) note that total phenolics decrease during thermal processing of foods, others (Dewanto et al., 2002) have reported no significant changes. Thus, the effect of drying treatments on phenolic compounds from different materials may not be the same.

\subsection{Antioxidant capacity}

Figure 4 shows the changes in antioxidant capacity of date samples as affected by drying method. The antioxidant capacity of fresh sample was found to be $1.40 \mu \mathrm{mol}$ Trolox/g d.w. After drying treatments, this value reached $2.08 \mu \mathrm{mol}$ Trolox/g d.w. for samples dried by microwave at $120 \mathrm{~W}(P<0.05)$. Date slices subjected to freeze drying $(1.48 \mu \mathrm{mol}$ Trolox/g d.w. $)$ had higher values $(P>0.05)$ than fresh sample but were significantly lower $(P \leq 0.05)$ than the microwave-dried and convective-dried samples at $60^{\circ} \mathrm{C}(1.87 \mu \mathrm{mol}$ Trolox/g d.w. $)$ and $70^{\circ} \mathrm{C}(1.66 \mu \mathrm{mol}$ Trolox/g d.w.). Additionally, there was not a significant $(P>0.05)$ difference between the antioxidant capacities of fresh sample and freeze and convective dried $\left(80^{\circ} \mathrm{C}, 1.53 \mu \mathrm{mol}\right.$ Trolox/g d.w. $)$ samples. Although non-thermal freeze drying is often considered to be the best drying method for preserving heat sensitive compounds, the results show that higher total phenolic content and antioxidant capacity were obtained with thermal methods for date fruit. Que et al. (2008) reported that hot air dried pumpkin flour contained higher total phenolic content and antioxidant activity than freeze dried sample, possibly due to production of Maillard products. The increase in antioxidant capacity as a result

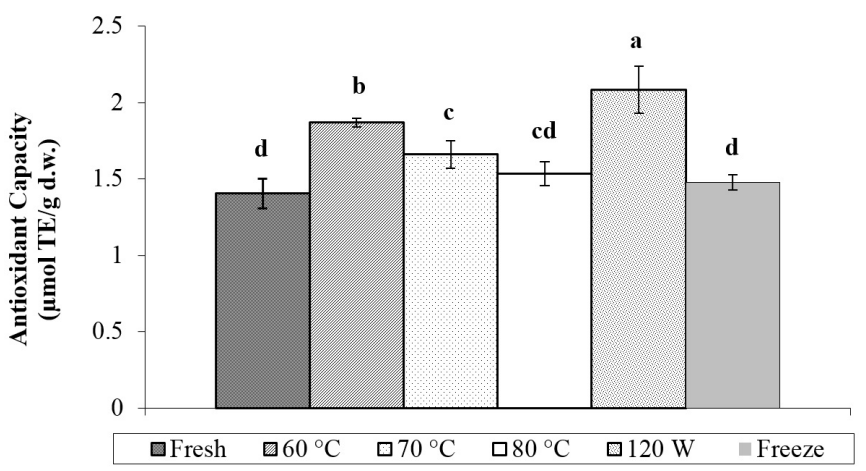

Figure 4. The effects of different drying conditions on the antioxidant capacity of dates. Bars that display different letters are shown as significantly different $(P<0.05)$. of drying might be caused by the formation of new antioxidant compounds (Albanese et al., 2013). In this study, the antioxidant capacity of samples increases in parallel with the total phenolic content. The antioxidant capacity of convective dried samples decreased as a consequence of increasing the drying temperature from 60 to $80^{\circ} \mathrm{C}$, possibly due to antioxidant compounds being relatively unstable at higher temperatures. The decrease could also be related to interactions between antioxidant compounds and other fruit constituents (Di Scala et al., 2011). These results disagree with some previous studies that reported that drying at low temperatures with long drying times decreases of antioxidant capacity (Garau et al., 2007; Vega-Gálvez et al., 2012).

\section{Conclusions}

In this study, using microwave power and increasing the temperature of convective drying caused significant decreases in drying time. Freeze drying was found to be the best method for maintaining good colour parameters. However, although freeze drying is often considered to be good for preserving heat-sensitive compounds, findings did not support that claim. The total phenolic content and antioxidant capacity of date slices were higher in dried samples than fresh samples. To model the drying behaviour of date slices, nine different thin-layer drying models were used to describe the drying kinetics. The model of Midilli et al. gave the best fit for the microwave application and all temperatures of convective drying, and the Two Term model showed the best fit for freeze drying. Overall, this study concludes that microwave drying shortens the drying time and can improve the final quality of dried date slices in terms of total phenolic content and antioxidant capacity.

\section{References}

Agrawal, Y. C., \& Singh, R. D. (1977). Thin layer drying studies on short grain rice. St. Joseph: ASAE. ASAE Paper, No 3531.

Albanese, D., Cinquanta, L., Cuccurullo, G., \& Di Matteo, M. (2013). Effects of microwave and hot $囚$ air drying methods on colour $\beta \bigotimes$ carotene and radical scavenging activity of apricots. International Journal of Food Science \& Technology, 48(6), 1327-1333. http:// dx.doi.org/10.1111/ijfs.12095.

Allaith, A. A. A. (2008). Antioxidant activity of Bahraini date palm (Phoenix dactylifera L.) fruit of various cultivars. International Journal of Food Science \& Technology, 43(6), 1033-1040. http:// dx.doi.org/10.1111/j.1365-2621.2007.01558.x.

Alothman, M., Bhat, R., \& Karim, A. A. (2009). Antioxidant capacity and phenolic content of selected tropical fruits from Malaysia extracted with different solvents. Food Chemistry, 115(3), 785-788. http://dx.doi.org/10.1016/j.foodchem.2008.12.005.

Al-Shahib, W., \& Marshall, R. J. (2003). The fruit of the date palm: its possible use as the best food for the future? International Journal of Food Sciences and Nutrition, 54(4), 247-259. http://dx.doi. org/10.1080/09637480120091982. PMid:12850886.

Ashraf, Z., \& Hamidi-Esfahani, Z. (2011). Date and date processing: a review. Food Reviews International, 27(2), 101-133. http://dx.doi. org/10.1080/87559129.2010.535231.

Ayensu, A. (1997). Dehydration of food crops using a solar dryer with convective heat flow. Solar Energy, 59(4-6), 121-126. http://dx.doi. org/10.1016/S0038-092X(96)00130-2. 
Carranza-Concha, J., Benlloch, M., Camacho, M. M., \& MartínezNavarrete, N. (2012). Effects of drying and pretreatment on the nutritional and functional quality of raisins. Food and Bioproducts Processing, 90(2), 243-248. http://dx.doi.org/10.1016/j.fbp.2011.04.002.

Chang, C. H., Lin, H. Y., Chang, C. Y., \& Liu, Y. C. (2006). Comparisons on the antioxidant properties of fresh freeze-dried and hot-air-dried tomatoes. Journal of Food Engineering, 77(3), 478-485. http://dx.doi. org/10.1016/j.jfoodeng.2005.06.061.

Chayjan, R. A., Salari, K., Abedi, Q., \& Sabziparvar, A. A. (2013). Modeling moisture diffusivity activation energy and specific energy consumption of squash seeds in a semi fluidized and fluidized bed drying. Journal of Food Science and Technology, 50(4), 667-677. http://dx.doi.org/10.1007/s13197-011-0399-8. PMid:24425968.

Dewanto, V., Wu, X., Adom, K. K., \& Liu, R. H. (2002). Thermal processing enhances the nutritional value of tomatoes by increasing total antioxidant activity. Journal of Agricultural and Food Chemistry, 50(10), 3010-3014. http://dx.doi.org/10.1021/jf0115589. PMid:11982434.

Di Scala, K., Vega-Gálvez, A., Uribe, E., Oyanadel, R., Miranda, M., Veragara, J., \& Quispe, I. (2011). Changes of quality characteristics of pepino fruit (Solanum muricatum Ait) during convective drying. International Journal of Food Science \& Technology, 46(4), 746-753. http://dx.doi.org/10.1111/j.1365-2621.2011.02555.x.

Doymaz, İ. (2005). Drying characteristics and kinetics of okra. Journal of Food Engineering, 69(3), 275-279. http://dx.doi.org/10.1016/j. jfoodeng.2004.08.019.

Doymaz, İ. (2013). Experimental study on drying of pear slices in a convective dryer. International Journal of Food Science \& Technology, 48(9), 1909-1915. http://dx.doi.org/10.1111/ijfs.12170.

Faal, S., Tavakoli, T., \& Ghobadian, B. (2015). Mathematical modelling of thin layer hot air drying of apricot with combined heat and power dryer. Journal of Food Science and Technology, 52(5), 2950-2957. http://dx.doi.org/10.1007/s13197-014-1331-9. PMid:25892795.

Garau, M. C., Simal, S., Rossello, C., \& Femenia, A. (2007). Effect of airdrying temperature on physico-chemical properties of dietary fibre and antioxidant capacity of orange (Citrus aurantium v. Canoneta) by-products. Food Chemistry, 104(3), 1014-1024. http://dx.doi. org/10.1016/j.foodchem.2007.01.009.

Goyal, R. K., Kingsly, A. R. P., Manikantan, M. R., \& Ilyas, S. M. (2006). Thin-layer drying kinetics of raw mango slices. Biosystems Engineering, 95(1), 43-49. http://dx.doi.org/10.1016/j.biosystemseng.2006.05.001.

Igual, M., García-Martínez, E., Martín-Esparza, M. E., \& MartínezNavarrete, N. (2012). Effect of processing on the drying kinetics and functional value of dried apricot. Food Research International, 47(2), 284-290. http://dx.doi.org/10.1016/j.foodres.2011.07.019.

Kammoun Bejar, A., Kechaou, N., \& Boudhrioua Mihoubi, N. (2011). Effect of microwave treatment on physical and functional properties of orange (Citrus Sinensis) peel and leaves. Journal of Food Processing \& Technology, 2(02), 109-116. http://dx.doi.org/10.4172/21577110.1000109 .

Kassem, A. S. (1998). Comparative studies on thin layer drying models for wheat. In Proceedings of the $13^{\text {th }}$ International Congress on Agricultural Engineering, Morocco.

Madamba, P. S., Driscoll, R. H., \& Buckle, K. A. (1996). The thin-layer drying characteristics of garlic slices. Journal of Food Engineering, 29(1), 75-97. http://dx.doi.org/10.1016/0260-8774(95)00062-3.

Maskan, M. (2000). Microwave/air and microwave finish drying of banana. Journal of Food Engineering, 44(2), 71-78. http://dx.doi. org/10.1016/S0260-8774(99)00167-3.
Maskan, M. (2001). Kinetics of colour change of kiwifruits during hot air and microwave drying. Journal of Food Engineering, 48(2), 169175. http://dx.doi.org/10.1016/S0260-8774(00)00154-0.

Midilli, A., Kucuk, H., \& Yapar, Z. (2002). A new model for singlelayer drying. Drying Technology, 20(7), 1503-1513. http://dx.doi.org/10.1081/ DRT-120005864.

Mundada, M., Hathan, B. S., \& Maske, S. (2010). Convective dehydration kinetics of osmotically pretreated pomegranate arils. Biosystems Engineering, 107(4), 307-316. http://dx.doi.org/10.1016/j. biosystemseng.2010.09.002.

Murthy, T. P. K., \& Manohar, B. (2014). Hot air drying characteristics of mango ginger: prediction of drying kinetics by mathematical modeling and artificial neural network. Journal of Food Science and Technology, 51(12), 3712-3721. http://dx.doi.org/10.1007/ s13197-013-0941-y.

Okos, M. R., Narsimhan, G., Singh, R. K., \& Weitnauer, A. C. (1992). Food dehydration. In D. R. Heldman \& D. B. Lund (Eds.), Handbook of food engineering (pp. 601-744). New York: Marcel Dekker.

Que, F., Mao, L., Fang, X., \& Wu, T. (2008). Comparison of hot air drying and freeze drying on the physicochemical properties and antioxidant activities of pumpkin (Cucurbita moschata Duch.) flours. International Journal of Food Science \& Technology, 43(7), 1195-1201. http://dx.doi.org/10.1111/j.1365-2621.2007.01590.x.

Ratti, C. (2001). Hot air and freeze-drying of high-value foods: a review. Journal of Food Engineering, 49(4), 311-319. http://dx.doi. org/10.1016/S0260-8774(00)00228-4.

Santos, S. C., Guiné, R. P., \& Barros, A. (2014). Effect of drying temperatures on the phenolic composition and antioxidant activity of pears of Rocha variety (Pyrus communis L.). Journal of Food Measurement and Characterization, 8(2), 105-112. http://dx.doi. org/10.1007/s11694-014-9170-y.

Sharaf-Eldeen, Y. I., Blaisdell, J. L., \& Hamdy, M. Y. (1980). A model for ear corn drying. Transactions of the ASAE, 23(5), 1261-1265. http://dx.doi.org/10.13031/2013.34757.

Singh, V., Guizani, N., Essa, M. M., Hakkim, F. L., \& Rahman, M. S. (2012). Comparative analysis of total phenolics flavonoid content and antioxidant profile of different date varieties (Phoenix dactylifera L.) from Sultanate of Oman. International Food Research Journal, 19(3), 1063-1070.

Sultana, B., Anwar, F., Ashraf, M., \& Saari, N. (2012). Effect of drying techniques on the total phenolic contents and antioxidant activity of selected fruits. Journal of Medicinal Plants Research, 6(1), 161-167.

Tavakolipour, H., \& Zirjani, L. (2014). Banana chips production by hot air and microwave dehydration methods: a comparative study. Middle East Journal of Scientific Research, 21(10), 1828-1836.

Tunde-Akintunde, T. Y., \& Ogunlakin, G. O. (2013). Mathematical modeling of drying of pretreated and untreated pumpkin. Journal of Food Science and Technology, 50(4), 705-713. http://dx.doi. org/10.1007/s13197-011-0392-2. PMid:24425972.

Turkmen, N., Sari, F., \& Velioglu, S. (2005). The effect of cooking methods on total phenolics and antioxidant activity of selected green vegetables. Food Chemistry, 93(4), 713-718. http://dx.doi. org/10.1016/j.foodchem.2004.12.038.

Vega-Gálvez, A., Ah-Hen, K., Chacana, M., Vergara, J., Martínez-Monzó, J., García-Segovia, P., Lemus-Mondaca, R., \& Di Scala, K. (2012). Effect of temperature and air velocity on drying kinetics antioxidant capacity total phenolic content colour texture and microstructure of apple (var. Granny Smith) slices. Food Chemistry, 132(1), 51-59. http://dx.doi.org/10.1016/j.foodchem.2011.10.029. PMid:26434262. 
Wang, C. Y., \& Singh, R. P. (1978). A single layer drying equation for rough rice. St. Joseph: ASAE. ASAE Paper, $\mathrm{N}^{\circ} 78-3001 .</$ bok $>$.

Wang, Z., Sun, J., Chen, F., Liao, X., \& Hu, X. (2007). Mathematical modelling on thin layer microwave drying of apple pomace with and without hot air pre-drying. Journal of Food Engineering, 80(2), 536-544. http://dx.doi.org/10.1016/j.jfoodeng.2006.06.019.

Westerman, P. W., White, G. M., \& Ross, I. J. (1973). Relative humidity effect on the high temperature drying of shelled corn. Transactions of the ASAE, 16(6), 1136-1139. http://dx.doi.org/10.13031/2013.37715.

Xiao, H. W., Yao, X. D., Lin, H., Yang, W. X., Meng, J. S., \& Gao, Z. J. (2012). Effect of SSB (superheated steam blanching) time and drying temperature on hot air impingement drying kinetics and quality attributes of yam slices. Journal of Food Process Engineering, 35(3), 370-390. http://dx.doi.org/10.1111/j.1745-4530.2010.00594.x.
Yagcioglu, A., Degirmencioglu, A., \& Cagatay, F. (1999). Drying characteristics of the laurel leaves under different drying conditions. In Proceedings of the 7th International Congress on Agricultural Mechanization and Energy, Adana, Turkey.

Yaldiz, O., Ertekin, C., \& Uzun, H. I. (2001). Mathematical modeling of thin layer solar drying of Sultana grapes. Energy, 26(5), 457-465. http://dx.doi.org/10.1016/S0360-5442(01)00018-4.

Zanoelo, E. F., Cardozo-Filho, L., \& Cardozo-Junior, E. L. (2006). Superheated steam drying of mate leaves and effect of drying conditions on the phenol content. Journal of Food Process Engineering, 29(3), 253-268. http://dx.doi.org/10.1111/j.1745-4530.2006.00064.x.

Zhang, M., Tang, J., Mujumdar, A., \& Wang, S. (2006). Trends in microwave related drying of fruits and vegetables. Trends in Food Science \& Technology, 17(10), 524-534. http://dx.doi.org/10.1016/j. tifs.2006.04.011. 